\title{
HONEY AND SUGAR AS SURROGATE PRODUCTS: AN EMERGY EVALUATION
}

\author{
E. SIMONCINI, F. COPPOLA, S. BORSA \& F.M. PULSELLI \\ Department of Chemistry, University of Siena, Italy.
}

\begin{abstract}
Exploitation of natural resources has reached an unsustainable level, due to the enormous growth of world population. Industrialized intensive agriculture, in particular, demands a great quantity of natural resources. White sugar is a widespread agricultural product. Its production from sugar beet or sugarcane is very expensive from the point of view of resource exploitation and sustainability. The aim of this paper is to compare white sugar and honey as sweeteners. We compared both processes of production in terms of emergy in order to establish the environmental costs and benefits of both. Transformities of honey and sugar were calculated per unit product and per unit area of land. Honey was found to have a better environmental performance than sugar production, due to the low quantity of non-renewable resources required. The environmental loading ratio indicated that honey production is more environmentally friendly than sugar production.

Keywords: agriculture, emergy, environmental loading ratio, honey, sugar, sugar beet, sugarcane, surrogate products.
\end{abstract}

\section{INTRODUCTION}

Agriculture has changed dramatically in the last fifty years. We have seen great development in food and fibre production, due to new technologies, mechanization, use of chemicals, and specialization. On the other hand, the costs have been significant. The major environmental costs are topsoil depletion, groundwater contamination, and the effects of massive use of fertilizers. The direct and indirect costs necessary to support this kind of agriculture make exploitation of natural resources unsustainable. Production of food and fibres implies degradation of natural resources: water (quality and quantity), soil erosion (accelerated by ploughing), and air pollution (e.g. greenhouse gas emissions from burning fossil fuels, nitrogen fertilizer production and use, excessive ploughing). Intensive and industrial agriculture depends on non-renewable energy sources, namely fossil fuels, which implies all the negative aspects related to the use of petroleum derivatives.

Sugar is a major industrialized agricultural product due to great annual demand. This widespread product is invariably derived from sugarcane or sugar beet. These crops demand many inputs [1]. Table 1 shows world sugar production and consumption in 2004-2005.

Since most environmental problems caused by sugar are related to mass production and consumption, analysis of other natural products as surrogates of sugar can be interesting.

Among the alternatives, that would also help to diversify the supply of agricultural products, in some cases safeguarding local production, honey is a possible substitute for sugar as sweetener.

In this paper, we evaluate the sustainability and environmental performance of honey and sugar production by an accounting methodology known as emergy evaluation. This method measures the work that nature does to support these processes, comparing them from the point of view of use of resources. It involves calculating and comparing different specific emergies.

Data on these production processes is available in the literature [2, 3], and a complete emergy assessment of honey and sugar production can be found in a Chinese study [4]. 
Table 1: World production and consumption of sugar [5].

\begin{tabular}{lcccc}
\hline & \multicolumn{2}{c}{ Production } & \multicolumn{2}{c}{$\begin{array}{c}\text { Consumption } \\
\text { (million tonnes, raw value) }\end{array}$} \\
\cline { 2 - 5 } & $2003-2004$ & $2004-2005$ & 2004 & 2005 \\
\hline Latin America/Caribbean & 47.0 & 47.8 & 25.7 & 26.1 \\
Africa & 5.1 & 5.3 & 8.0 & 8.1 \\
Near East & 5.3 & 5.7 & 10.8 & 11.0 \\
Far East & 41.7 & 42.1 & 50.8 & 50.9 \\
Oceania & 0.4 & 0.4 & 0.1 & 0.1 \\
Developing countries & $\mathbf{9 9 . 5}$ & $\mathbf{1 0 1 . 3}$ & $\mathbf{9 5 . 4}$ & $\mathbf{9 6 . 2}$ \\
Europe & 20.9 & 21.8 & 20.5 & 20.3 \\
Of which: European Union & 16.8 & 17.8 & 15.0 & 14.9 \\
North America & 8.2 & 8.2 & 10.3 & 10.9 \\
Commonwealth of & 4.2 & 4.0 & 11.3 & 11.7 \\
Independent States & & & & \\
Oceania & 5.1 & 5.2 & 1.4 & 1.4 \\
Others & 3.3 & 3.5 & 4.4 & 4.3 \\
Of which: South Africa & 2.4 & 2.6 & 1.6 & 1.6 \\
Developed countries & $\mathbf{4 1 . 7}$ & $\mathbf{4 2 . 7}$ & $\mathbf{4 7 . 9}$ & $\mathbf{4 8 . 6}$ \\
World & $\mathbf{1 4 1 . 0}$ & $\mathbf{1 4 4 . 0}$ & $\mathbf{1 4 3 . 3}$ & $\mathbf{1 4 4 . 8}$ \\
\hline
\end{tabular}

\section{METHODS}

Goal functions have been developed to measure the efficiency and performance of processes from a holistic point of view. Among these functions, emergy [6] is mainly used to evaluate the work done by nature to provide a product or support a process. It is therefore an appropriate function for accounting consumption of natural resources in man-made systems.

'Emergy is defined as the available energy directly and indirectly used up to make a service or product'. Its unit is the emjoule (ej) [7] and its physical dimensions are those of energy $\left(\mathrm{ML}^{2} \mathrm{~T}^{-2}\right)$, though it is not a state function, since it depends on the characteristics of the process. Since all processes in the biosphere are driven by solar energy, it is natural to take this type of energy as common denominator and use solar emergy expressed in solar emjoules (sej). Emergy is thus defined as the solar energy required (directly or indirectly) to make a product. Solar emergy measures the different energies converging in systems, processes or products and is sometimes referred to as "energy memory' [7]. We can view emergy as the work the biosphere must do to maintain a system far from equilibrium or to reproduce an item once it has been consumed.

The total emergy flowing through a system in unit time is called empower, measured in sej/[time] [7] with physical dimensions $\mathrm{ML}^{2} \mathrm{~T}^{-3}$ as for power. The basis of emergy analysis is the conversion of all inputs of a process, both energy and materials, into the same unit (emergy) by a conversion factor called transformity. Transformity is the intensive correspondent of emergy: it is not a state function, and it is dimensionless, though it is usually expressed in solar emjoules per joule (sej/J), reflecting the 
fact that the numerator is a sum of solar emergies, while the denominator is energy in the form token by the product of the process; when expressed in terms of solar emjoules per gram (sej/g), this entity is called specific emergy. Transformity (or specific emergy) is the emergy per unit flow of energy or matter. It is thus a property of that specific flow. Comparisons between transformities of homogeneous items provide information about production efficiency: the higher the transformity, the lower the efficiency (the more emergy is needed to produce the same amount of product).

In general, the second law of thermodynamics states that a portion of energy is dissipated (into unusable form) during transformation from one form of energy to another. Consequently, the quantity of usable energy decreases at each new level. Instead, emergy, following a memorization rather than a conservation logic, tends to increase, and transformities therefore also increase. According to Odum, 'Energy flows of the universe are organized in an energy transformation hierarchy... the position in the energy hierarchy is measured with transformities' [7].

Here we used emergy evaluation to compare sugar and honey production processes; the transformities obtained represent the efficiency with which natural inputs are used to obtain the final product. These inputs can be classified into three categories: $\mathrm{R}$ - local renewable resources; $\mathrm{N}$ - local nonrenewable resources; and $\mathrm{F}$ - feedback inputs purchased outside the system. The environmental loading ratio (ELR), a sustainability indicator, is the emergy of inputs from outside the studied system (i.e. from economic system) and from local non-renewable resources divided by the emergy from local renewable resources. It indicates the environmental impact of the two systems under study. Formally:

$$
\operatorname{ELR}=(\mathrm{N}+\mathrm{F}) / \mathrm{R}
$$

where $\mathrm{N}$ is all non-renewable inputs, $\mathrm{F}$ is all external flows, and $\mathrm{R}$ is natural, renewable flows.

A high ELR reflects high environmental stress and/or a high level of technology, and it increases when less renewable inputs are used. In this way, we can determine which of the two processes is more environmentally friendly from the point of view of exploitation of natural resources. In our calculation, we used emergy flows per hectare of land used per year.

We used transformities based on a global emergy flow of $15.83 \times 10^{24} \mathrm{sej} / \mathrm{year}[8,9]$; therefore, all transformities based on a flow of $9.44 \times 10^{24} \mathrm{sej} / \mathrm{year}$ [7], were multiplied by 1.68 .

\subsection{The sugar system}

Sugar production has an agricultural and an industrial phase. The former produces a raw plant product, which is converted into the final product, white sugar, by various physical and chemical processes. White and raw sugar can be obtained from sugarcane and sugar beet. Since sugarcane needs a great amount of water and a tropical climate, we only considered sugar beet. The agricultural phase consists of:

- soil preparation,

- sowing of beet,

- application of pesticides, and

- harvest.

The main input is fossil fuels, used by farm machinery in each step. Beet is a biennial cultivation; only $20 \%$ weight/weight (w/w) of the agricultural product is converted into white sugar [10].

The industrial phase consists of:

- extraction of raw juice,

- purification of juice, 


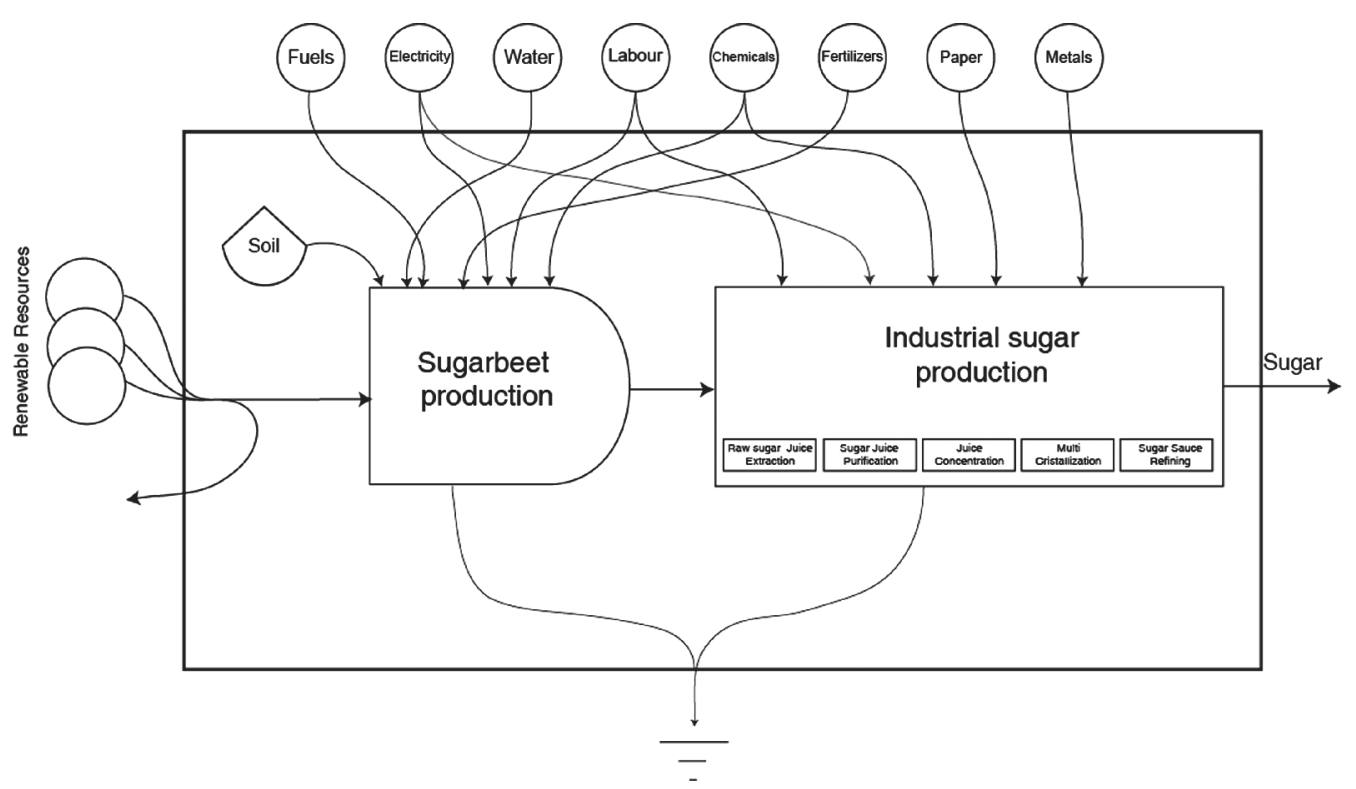

Figure 1: Energy diagram of production of sugar from beet.

- juice concentration,

- multi-crystallization or 'cooking', and

- sugar sauce refining.

The main inputs are chemicals, such as sodium carbonate $\left(\mathrm{Na}_{2} \mathrm{CO}_{3}\right)$, coal, and electricity. In sugar production from sugarcane, most of the energy of the process may be obtained from burning bagasse, whereas in sugar beet processing by-products are disposed into wastewaters.

Our emergy analysis of white sugar production from sugar beet was mainly based on life cycle analysis (LCA) schemes: due to the lack of complete studies on sugar production in Italy, we assumed a standard production process of beet based on data in the literature. Major matter and energy flow inputs were drawn from an LCA performed in Denmark [10]; data on machinery was obtained in Italy [11]; data on human labour was obtained from an LCA of Brazilian sugar production [2]. For natural renewable inputs (insolation, precipitation, and wind), we used data for the Calabria region, in the south of Italy, the region we used to study honey production.

The steps of the process refer to 1 ha of agricultural land that produced 4.95 metric tons of white sugar; all inputs, including farm and industrial machinery, were assumed to have a life of 30 years. Soil erosion was also considered, since sugar beet is an intensive agricultural practice. Figure 1 shows the energy diagram of the sugar production system, including relations between natural resources and the final product, and all flows of energy and material.

\subsection{The honey system}

Honey production is supported by ecosystems and agricultural systems. An almost 'natural' agricultural system leads to the final product that is obtained through a low-impact 'industrial' process. We assumed that natural honey production and the respective man-made support do not depend on 
surrounding agricultural and/or ecosystem conditions. Bees collect pollen to feed themselves and their pupae; eggs and pupae hatch in cells of the favus, in natural ecosystems, or in a beehive. Beehives are wooden boxes with metal frames, containing beeswax sheets on which bees build the honeycomb. Bees bring nectar and pollen to the queen bee and nurses, which feed the pupae. Nurses digest pollen, producing honey, which is therefore simultaneously a plant and animal product. If the hive contains more than enough frames, the nurses produce more honey than the society needs. To produce $1 \mathrm{~g}$ of honey for humans, an average of $6.67 \mathrm{~g}$ of honey has to be produced for the bees. This overproduction is done by the bees as a matter of course.

The pollen harvest lasts from spring to the end of summer. Once the honey is produced, the honeycomb seal is removed manually and the honeycombs are spun in a centrifuge. The honey is collected, filtered, and stored in glass jars. Hence, industrial steps leading to the final product are very simple and require only simple machinery, and little labour, energy, and materials.

Our emergy analysis of honey production was based on a case study in Calabria, southern Italy, in a site on the Ionian coast. Data for solar irradiation, precipitation, and wind speed were site specific. Soil erosion was negligible, as honey production does not depend on agricultural cultivation. Data on bee breed and honey processes were obtained in a local honey farm. Bees scavenge an area of 4 ha. Honey production involves no more than two people, working a total of 238/year (personal communication). For an annual production of 2.5 metric tons, $5.62 \times 10^{5} \mathrm{~J}$ of electricity is consumed for lighting and the centrifuge, making electricity the main input (personal communication). Transport and building facilities are minor entries in the process, compared with white sugar production. Process inputs were allocated per hectare of grassland scavenged by bees; the final output was $625 \mathrm{~kg} / \mathrm{ha}$ of honey for human consumption.

Figure 2 is the energy diagram of honey production. It shows relations between natural resources and the final product, as well as all flows of energy and material involved.

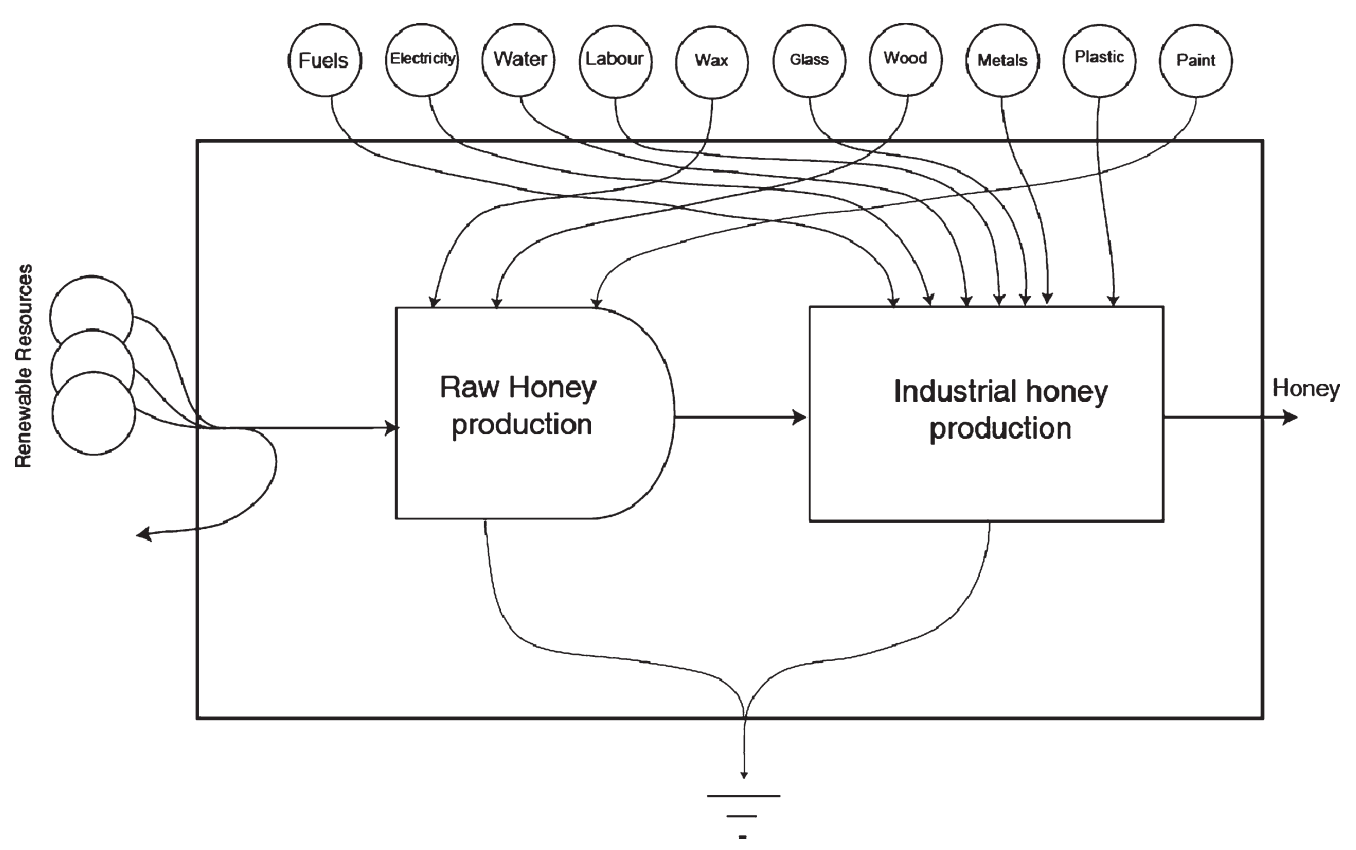

Figure 2: Energy diagram of honey production. 


\section{RESULTS}

\subsection{The sugar system}

Table 2 shows that industrial phase, namely, from extraction of raw juice to sugar sauce, is the most expensive in emergy terms. The amount of emergy involved in this phase is about 20 times greater than the emergy of the agricultural phase $\left(4.01 \times 10^{17}\right.$ sej versus $1.92 \times 10^{16}$ sej, respectively, per hectare). Major items are coal, metals (steel and iron, $8.78 \times 10^{16} \mathrm{sej} / \mathrm{ha}$ and $2.03 \times 10^{17} \mathrm{sej} / \mathrm{ha}$, respectively), and water. In the agricultural phase, the main inputs are fertilizers, pesticides, and loss of topsoil; in fact, the principal flow in this phase is nitrogen $\left(7.71 \times 10^{15} \mathrm{sej} / \mathrm{ha}\right)$, whereas fuel oil for agricultural operations is only $3.03 \times 10^{12} \mathrm{sej} / \mathrm{ha}$.

Table 2: Emergy evaluation of white sugar from beet.

\begin{tabular}{|c|c|c|c|c|c|}
\hline & Quantity/ha & Unit & $\begin{array}{l}\text { Transformity } \\
\text { (sej/unit) }\end{array}$ & Ref. & Emergy (sej) \\
\hline \multicolumn{6}{|l|}{ Renewable resources } \\
\hline Insolation & $5.77 \mathrm{E}+13$ & $\mathrm{~J}$ & 1 & By definition & $5.77 \mathrm{E}+13$ \\
\hline Precipitation & $7.65 \mathrm{E}+09$ & $\mathrm{~J}$ & $1.45 \mathrm{E}+05$ & {$[8]$} & $1.11 \mathrm{E}+15$ \\
\hline Wind & $8.82 \mathrm{E}+10$ & $\mathrm{~J}$ & $2.45 \mathrm{E}+03$ & [8] & $2.16 \mathrm{E}+14$ \\
\hline \multirow[t]{2}{*}{ Geothermal heat } & $6.00 \mathrm{E}+09$ & $\mathrm{~J}$ & $4.28 \mathrm{E}+03$ & {$[8]$} & $2.57 \mathrm{E}+13$ \\
\hline & & & & & $1.13 E+15$ \\
\hline \multicolumn{6}{|l|}{ Non-renewables } \\
\hline Soil loss & $4.88 \mathrm{E}+08$ & $\mathrm{~J}$ & $1.24 \mathrm{E}+05$ & [8] & $6.05 \mathrm{E}+13$ \\
\hline $\mathrm{N}$ & $9.94 \mathrm{E}+05$ & $\mathrm{~g}$ & $7.76 \mathrm{E}+09$ & {$[7]$} & $7.71 \mathrm{E}+15$ \\
\hline $\mathrm{P}$ & $2.48 \mathrm{E}+05$ & $\mathrm{~g}$ & $2.99 \mathrm{E}+10$ & [7] & $7.43 \mathrm{E}+15$ \\
\hline $\mathrm{K}$ & $9.94 \mathrm{E}+05$ & g & $1.85 \mathrm{E}+09$ & {$[7]$} & $1.84 \mathrm{E}+15$ \\
\hline $\mathrm{Na}$ & $4.14 \mathrm{E}+05$ & g & $1.07 \mathrm{E}+09$ & {$[9]$} & $4.44 \mathrm{E}+14$ \\
\hline $\mathrm{Mg}$ & $1.24 \mathrm{E}+05$ & $\mathrm{~g}$ & $1.07 \mathrm{E}+09$ & {$[9]$} & $1.33 \mathrm{E}+14$ \\
\hline S & $4.14 \mathrm{E}+05$ & g & $1.07 \mathrm{E}+09$ & {$[9]$} & $4.44 \mathrm{E}+14$ \\
\hline Pesticides & $2.90 \mathrm{E}+04$ & g & $1.07 \mathrm{E}+09$ & {$[9]$} & $3.11 \mathrm{E}+13$ \\
\hline \multirow[t]{2}{*}{ Fuel oil } & $2.76 \mathrm{E}+07$ & $\mathrm{~J}$ & $1.10 \mathrm{E}+05$ & {$[12]$} & $3.03 \mathrm{E}+12$ \\
\hline & & & & & $1.81 E+16$ \\
\hline Agricultural phase & & & & & $1.92 E+16$ \\
\hline Electricity & $5.09 \mathrm{E}+04$ & $\mathrm{~J}$ & $2.07 \mathrm{E}+05$ & {$[7]$} & $1.05 \mathrm{E}+10$ \\
\hline Water & $5.20 \mathrm{E}+09$ & g & $1.95 \mathrm{E}+06$ & {$[13]$} & $1.01 \mathrm{E}+16$ \\
\hline Fuel oil & $1.38 \mathrm{E}+09$ & $\mathrm{~J}$ & $1.13 \mathrm{E}+05$ & {$[12]$} & $1.56 \mathrm{E}+14$ \\
\hline
\end{tabular}

(continued) 
Table 2: (Continued)

\begin{tabular}{|c|c|c|c|c|c|}
\hline & Quantity/ha & Unit & $\begin{array}{l}\text { Transformity } \\
\text { (sej/unit) }\end{array}$ & Ref. & Emergy (sej) \\
\hline Coal & $4.63 \mathrm{E}+07$ & $\mathrm{~g}$ & $1.97 \mathrm{E}+09$ & {$[7]$} & $9.12 \mathrm{E}+16$ \\
\hline $\mathrm{Na}_{2} \mathrm{CO}_{3}$ & $1.35 \mathrm{E}+05$ & $\mathrm{~g}$ & $1.07 \mathrm{E}+09$ & {$[9]$} & $1.45 \mathrm{E}+14$ \\
\hline $\mathrm{SO}_{2}$ & $3.24 \mathrm{E}+04$ & $\mathrm{~g}$ & $1.07 \mathrm{E}+09$ & {$[9]$} & $3.47 \mathrm{E}+13$ \\
\hline $\mathrm{H}_{2} \mathrm{SO}_{4}$ & $8.96 \mathrm{E}+04$ & $\mathrm{~g}$ & $1.07 \mathrm{E}+09$ & {$[9]$} & $9.61 \mathrm{E}+13$ \\
\hline $\mathrm{Ca}(\mathrm{OH})_{2}$ & $9.62 \mathrm{E}+03$ & $\mathrm{~g}$ & $1.07 \mathrm{E}+09$ & {$[9]$} & $1.03 \mathrm{E}+13$ \\
\hline \multirow[t]{2}{*}{ Formaldehyde } & $2.74 \mathrm{E}+04$ & $\mathrm{~g}$ & $1.07 \mathrm{E}+09$ & {$[9]$} & $2.94 \mathrm{E}+13$ \\
\hline & & & & & $1.02 E+17$ \\
\hline \multicolumn{6}{|l|}{$\begin{array}{l}\text { Machinery and } \\
\text { packaging }\end{array}$} \\
\hline Steel & $1.26 \mathrm{E}+07$ & $\mathrm{~g}$ & $6.97 \mathrm{E}+09$ & [14] & $8.78 \mathrm{E}+16$ \\
\hline Copper & $4.73 \mathrm{E}+04$ & $\mathrm{~g}$ & $1.04 \mathrm{E}+11$ & [14] & $4.91 \mathrm{E}+15$ \\
\hline Iron & $2.92 \mathrm{E}+07$ & $\mathrm{~g}$ & $6.97 \mathrm{E}+09$ & [14] & $2.03 \mathrm{E}+17$ \\
\hline \multirow[t]{2}{*}{ Paper } & $5.13 \mathrm{E}+05$ & $\mathrm{~g}$ & $6.55 \mathrm{E}+09$ & [15] & $3.36 \mathrm{E}+15$ \\
\hline & & & & & $2.99 E+17$ \\
\hline Industrial phase & & & & & $4.01 E+17$ \\
\hline Human labour & $1.70 \mathrm{E}+10$ & $\mathrm{~J}$ & $1.24 \mathrm{E}+07$ & {$[3]$} & $2.10 E+17$ \\
\hline $\begin{array}{l}\text { White sugar from } \\
\text { sugar beet }\end{array}$ & $1.00 \mathrm{E}+00$ & ha & & & $6.31 E+17$ \\
\hline $\begin{array}{l}\text { White sugar from } \\
\text { sugar beet }\end{array}$ & $4.50 \mathrm{E}+07$ & $\mathrm{~g}$ & $1.40 \mathrm{E}+10$ & & \\
\hline
\end{tabular}

To better understand the environmental impact of the system, the ELR was calculated for sugar beet production, dividing all non-renewable inputs (non-renewable agricultural inputs, industrial inputs, and $75 \%$ of human labour) by all renewable inputs (natural resources and $25 \%$ of human labour). The result indicates the dependence of this production process on non-renewable resources, both indigenous and imported.

$$
\mathrm{ELR}_{\text {Sugar }}=\frac{\left(\mathrm{Em}_{\text {Non-renewableAgricultural }}+\mathrm{Em}_{\text {IndustrialPhase }}+75 \% \mathrm{Em}_{\text {Labour }}\right)}{\left(\mathrm{Em}_{\text {RenewableNaturalSources }}+25 \% \mathrm{Em}_{\text {Labour }}\right)}
$$

The ELR for white sugar production from sugar beet is about 10.74, due to the nature of the main inputs, most of which come from outside the system. This is a remarkable point, underlining the heavy environmental load of sugar production with its consumption of coal, water, fertilizers, and metals (steel, iron, and copper) and dependence on other ecosystems and the economic system. 


\subsection{The honey system}

In honey production (Table 3), the 'ecosystem phase' is fed by an emergy flow of $1.13 \times 10^{15}$ sej/ha. Human support was negligible. The infrastructure for hosting bees (beehives) is almost negligible $(1.89 \times$ $10^{11} \mathrm{sej} / \mathrm{ha}$, mainly wood). The so-called 'industrial phase', including inputs necessary for collecting honey, was only about $2.13 \times 10^{13} \mathrm{sej}$. The major non-renewable inputs were iron $\left(2.10 \times 10^{13} \mathrm{sej} / \mathrm{ha}\right)$, human labour $\left(3.86 \times 10^{10} \mathrm{sej} / \mathrm{ha}\right)$, and electricity for the centrifuge $\left(2.91 \times 10^{10} \mathrm{sej} / \mathrm{ha}\right)$.

Table 3: Honey emergy flow.

\begin{tabular}{|c|c|c|c|c|c|}
\hline & Quantity/ha & Unit & $\begin{array}{l}\text { Transformity } \\
\text { (sej/unit) }\end{array}$ & Ref. & Emergy (sej) \\
\hline \multicolumn{6}{|l|}{ Renewable resources } \\
\hline Insolation & $5.77 \mathrm{E}+13$ & $\mathrm{~J}$ & $1.00 \mathrm{E}+00$ & Definition & $5.77 \mathrm{E}+13$ \\
\hline Precipitation & $7.65 \mathrm{E}+09$ & $\mathrm{~g}$ & $1.45 \mathrm{E}+05$ & [11] & $1.11 \mathrm{E}+15$ \\
\hline Wind & $8.82 \mathrm{E}+10$ & $\mathrm{~J}$ & $2.45 \mathrm{E}+03$ & [11] & $2.16 \mathrm{E}+14$ \\
\hline \multirow[t]{2}{*}{ Geothermal heat } & $6.00 \mathrm{E}+09$ & $\mathrm{~J}$ & $4.28 \mathrm{E}+03$ & {$[11]$} & $2.57 \mathrm{E}+13$ \\
\hline & & & & & $1.13 E+15$ \\
\hline \multicolumn{6}{|l|}{ Non-renewables } \\
\hline Wood & $6.16 \mathrm{E}+01$ & g & $2.40 \mathrm{E}+09$ & [7] & $1.48 \mathrm{E}+11$ \\
\hline Wax (chemical) & $2.93 \mathrm{E}+01$ & $\mathrm{~g}$ & $1.07 \mathrm{E}+09$ & {$[2]$} & $3.14 \mathrm{E}+10$ \\
\hline \multirow[t]{2}{*}{ Paint } & $3.75 \mathrm{E}-01$ & g & $2.55 E+10$ & {$[14]$} & $9.58 \mathrm{E}+09$ \\
\hline & & & & & $1.89 E+11$ \\
\hline $\begin{array}{l}\text { Ecosystem support } \\
\text { and human } \\
\text { infrastructure }\end{array}$ & & & & & $1.13 E+15$ \\
\hline Iron & $3.01 \mathrm{E}+03$ & g & $6.97 \mathrm{E}+09$ & {$[14]$} & $2.10 \mathrm{E}+13$ \\
\hline Glass & $1.88 \mathrm{E}+02$ & g & $1.41 \mathrm{E}+09$ & {$[7]$} & $2.65 \mathrm{E}+11$ \\
\hline Water & $7.50 \mathrm{E}+03$ & g & $1.95 \mathrm{E}+06$ & {$[13]$} & $1.46 \mathrm{E}+10$ \\
\hline Electric energy & $1.40 \mathrm{E}+05$ & $\mathrm{~J}$ & $2.07 \mathrm{E}+05$ & {$[16]$} & $2.91 \mathrm{E}+10$ \\
\hline \multirow[t]{2}{*}{ Fuel } & $2.69 \mathrm{E}+01$ & $\mathrm{~J}$ & $1.13 \mathrm{E}+05$ & {$[12]$} & $3.04 \mathrm{E}+06$ \\
\hline & & & & & $2.13 E+13$ \\
\hline Industrial phase & & & & & $2.13 E+13$ \\
\hline Human work & $3.11 \mathrm{E}+03$ & $\mathrm{~J}$ & $1.24 \mathrm{E}+07$ & {$[3]$} & $3.86 E+10$ \\
\hline $\begin{array}{l}\text { Honey (product for } \\
\text { human) per hectare }\end{array}$ & 1 & ha & $1.16 E+15$ & & $1.16 \mathrm{E}+15$ \\
\hline $\begin{array}{l}\text { Honey (product for } \\
\text { human) per gram }\end{array}$ & $6.25 \mathrm{E}+05$ & g & $1.85 E+09$ & & \\
\hline
\end{tabular}


Besides the production of honey, bees and their work are essential for sustaining agriculture, because they increase the percentage of flowers pollinated [16-18]. Obviously, the intrinsic value of this service was not included in our analysis.

The ELR of honey production was 0.02 , obtained by dividing non-renewable and external flows by renewable ones.

$$
\mathrm{ELR}=\frac{\left(\mathrm{Em}_{\text {Non-renewablelenfrastructure }}+\mathrm{Em}_{\text {IndustrialPhase }}+75 \% \mathrm{Em}_{\text {Labour }}\right)}{\left(\mathrm{Em}_{\text {RenewableNaturalSources }}+25 \% \mathrm{Em}_{\text {Labour }}\right)}
$$

This surprising different ELR is the result of fewer external inputs and the nature of the production system, which involves no agricultural phase and negligible human labour.

\section{DISCUSSION AND CONCLUSIONS}

A famous saying is attributed to Albert Einstein: 'If the bee disappears from the surface of the earth, man will have no more than four years to live. No more bees, no more pollination... no more man!' The importance of bees as pollinators emerges from this statement as well as from many other studies [18-21].

The specific emergies of sugar and honey calculated here were $1.40 \times 10^{10}$ and $1.85 \times 10^{9} \mathrm{sej} / \mathrm{g}$, respectively. Emergies per hectare were $6.31 \times 10^{17}$ and $1.16 \times 10^{15}$ sej/ha, respectively. Since honey production is more extensive than that of sugar, it requires much less emergy per unit land per unit product (not comparing products, but overall production systems).

Theoretically, it is not possible to compare these two processes, since their outputs are different from many points of view. Analysis of the two emergy flows per hectare simply shows the difference in their inputs of natural resources. Non-renewable inputs for honey are very low $\left(2.15 \times 10^{13} \mathrm{sej} / \mathrm{ha}\right)$, but there is a greater flow of renewable resources $\left(1.13 \times 10^{15} \mathrm{sej} / \mathrm{ha}\right)$, so the work performed by bees substitutes the entire agricultural phase and simplifies the industrial one.

Comparison of ELR is a way to focus on differences between the flows of the two processes, 10.74 for sugar and 0.02 for honey, calculated using emergy per hectare flow data. The huge difference between these values means that sugar production has an industrial base, whereas most emergy of honey is derived from renewable resources. Agricultural systems demand much fossil fuel (for transport, fertilizers, ploughing, sowing, and harvesting). This problem could be partially solved if a portion of fossil fuel was replaced by fuel from biomass (e.g. sunflower oil). This would decrease the ELR, especially if sunflower production was integrated in the same agricultural system. Thus, emergy analysis shows that honey production depends substantially on renewable natural resources, and that raw honey production by bees is independent of human activity. ELR and emergy per hectare revealed that bees' natural activities replace part of the industrial phase. The work of bees at trophic level corresponds to human labour in the agricultural phase and a portion of the industrial phase of the sugar system. In fact, in sugar production, human work represents more than $50 \%$ of total emergy, whereas in the honey system human work is almost negligible. The industrial part of sugar production corresponds to the work of bees that transform raw plant carbohydrates (nectar or pollen) into a pure food. Bees collect pollen for their own lives, irrespective of any human activity. A minimum interaction with humans (construction of beehives) allows bees to produce more honey as a by-product. The honey only has to be extracted from the honeycombs by centrifuging.

Since sugar and honey are dissimilar products and their production processes are structurally different, we can compare the emergy results on the basis of sweetening power (SP) [22]. This is usually based on the concentration of sugars in a food compared to sucrose (refined sugar). Table 4 shows the specific emergy (sej/g) and transformity (sej/J), calculated from the calorie content of the 
Table 4: Energy-based comparison.

\begin{tabular}{lcccccc}
\hline & $\mathrm{cal} / \mathrm{g}$ & $\mathrm{J} / \mathrm{g}$ & $\mathrm{sej} / \mathrm{g}$ & $\mathrm{sej} / \mathrm{J}$ & Sweetening power & sej/SP \\
\hline Honey & 3.2 & 13.4 & $1.85 \mathrm{E}+09$ & $1.38 \mathrm{E}+08$ & 1.5 & $1.23 \mathrm{E}+09$ \\
White sugar & 4 & 16.7 & $1.40 \mathrm{E}+10$ & $8.37 \mathrm{E}+08$ & 1 & $1.40 \mathrm{E}+10$ \\
\hline
\end{tabular}

two sweeteners (in cal/g and J/g), and the emergy per SP, assessed by taking that of white sugar as one. The SP of honey was found to be 1.5 times that of white sugar [22].

If we consider the two products on the basis of SP, the difference between the specific emergies of honey and sugar increases. Since the SP of these products is associated with the nutrients they contain, the ratio of emergy to the SP (sej/SP) is a better indication than transformity (sej/J). With regard to the final use of these products, emergy analysis provides a useful description of their environmental impacts, a qualitative and quantitative indication profile of their production characteristics and a measure of their pressure on natural ecosystems.

Furthermore, honey is not only composed of sucrose, but also contains fructose (about 38\%), amino acids (about 1\%), trace minerals, enzymes, and organic acids, whereas white sugar is $98-100 \%$ sucrose, making honey a more complete food [22, 23, 24].

Our emergy analyses lead to new values of specific emergy for sugar (a standard production system was assumed) and for a small-scale honey production in Italy. A look at ELR and SP suggested that honey production is a feasible way of reducing the consumption of non-renewable inputs exploited by the sugar industry. Honey is therefore a good surrogate for white sugar.

\section{REFERENCES}

[1] International sugar statistics, www.ilovesugar.com/worldofsugar/internationalSugarStats.htm

[2] Ometto, A.R., Roma, W.L.N. \& Ortega, E., Emergy life cycle assessment of fuel ethanol in Brazil, Proc. of IV Biennial International Workshop 'Advances in Energy Studies'. Unicamp, Campinas: SP, Brazil, pp. 389-399, 2004.

[3] Ulgiati, S., Odum, H.T. \& Bastianoni, S., Emergy use, environmental loading and sustainability an emergy analysis of Italy. Ecological Modelling, 73, pp. 215-268, 1994. doi:10.1016/0304$\underline{3800(94) 90064-7}$

[4] Jiang, M.M., Chen, B., Zhou, J.B., Tao, F.R., Li, Z., Yang, Z.F. \& Chen, G.Q., Emergy account for biomass resource exploitation by agriculture in China. Energy Policy, 35, pp. 4704-4714, 2007. doi:10.1016/j.enpol.2007.03.014

[5] Food and Agriculture Organization of the United Nations, World sugar production forecast to increase in 2004/05, 2004.

[6] Bastianoni, S., Emergy, empower and eco-exergy to empower ratio: a reconciliation of H.T. Odum with Prigogine? International Journal of Ecodynamics, 1(3), pp. 227-235, 2006.

[7] Odum, H.T., Environmental Accounting: Emergy and Environmental Decision Making, Wiley: New York, 1996.

[8] Odum, H.T., Handbook of Emergy Evaluation Folio 2: Emergy of Global Processes, Center for Environmental Policy, University of Florida: Gainesville, USA, 2000.

[9] Odum, H.T., Brown, M.T. \& Brandt-Williams, S., Handbook of Emergy Evaluation Folio 1: Introduction and Global Budget, Center for Environmental Policy, University of Florida: Gainesville, USA, 2000. 
[10] Factor, G., Longin, E., Villanueva, A. \& Welton, C., Life Cycle Assessment of Sugar Production. Cane Sugar versus Beet Sugar, Final Report, Technical University of Denmark, 1998.

[11] Bertuzzi, S., Cecchini, F., Fantin, V., Franchini, F., Neri, P. \& Spadoni, G., Analisi del ciclo di vita dello zucchero da barbabietola, ENEA, Protocol no. P135-057, 2005.

[12] Bastianoni, S., Campbell, D., Susani, L. \& Tiezzi, E., The solar transformity of oil and petroleum natural gas. Ecological Modelling, 186, pp. 212-220, 2005. doi:10.1016/j.ecolmodel.2005.01.015

[13] Odum, H.T., Systems Ecology, John Wiley \& Sons Inc.: New York, 1983.

[14] Brandt-Williams, S., Handbook of Emergy Evaluation Folio 4: Emergy of Florida Agriculture, Center for Environmental Policy, University of Florida: Gainesville, USA, 2002.

[15] Vorasun, B., Evaluation of recycling and reuse of building materials using the emergy analysis method, University of Florida, Ph.D. Thesis, 1998.

[16] Brown, M.T. \& Bardi, E., Handbook of Emergy Evaluation Folio 3: Emergy of Ecosystems, Center for Environmental Policy, University of Florida: Gainesville, USA, 2001.

[17] Odum, H.T., Emergy and Public Policy, Part I-II, Environmental Engineering Sciences, University of Florida: Gainsville, FL, 1992.

[18] Greenleaf, S.S. \& Kremen, C., Wild bee species increase tomato production and respond differently to surrounding land use in Northern California. Biological Conservation, 133, pp. 81-87, 2006. doi:10.1016/j.biocon.2006.05.025

[19] British Bee Book: A Biography (1500-1976). International Bee Research Association: London, 1979.

[20] Pinzauti, M., Api e Impollinazione, Regione Toscana: Firenze, 2000.

[21] Philippe, J.-M., La pollination par les abeilles, Edisud: Aix-en-Provence, 1991.

[22] http://www.alive.com/1990a5a2.php?subject_bread_cramb=7

[23] Atti del convegno 'Il ruolo della ricerca in apicoltura', Istituto Nazionale Apicoltura: Bologna, 2002.

[24] http://www.foodreference.com/html/art-honey-health.html 